Regulasi Diri Mahasiswa Bimbingan dan Konseling Dalam Proses Penyusunan Skripsi

\title{
REGULASI DIRI MAHASISWA BIMBINGAN DAN KONSELING DALAM PROSES PENYUSUNAN SKRIPSI \\ (Survey Mahasiswa Bimbingan dan Konseling Angkatan 2008-2010 yang Bekerja)
}

\author{
Arip Nazarudin ${ }^{1}$ \\ Dra. Indira Chanum, M.Psi. ${ }^{2}$ \\ Happy Karlina Marjo, M.Pd. Kons. ${ }^{3}$
}

\begin{abstract}
Abstrak
Penelitian ini bertujuan untuk mendapatkan gambaran mengenai regulasi diri mahasiswa Bimbingan dan Konseling angkatan 2008-2010 Fakultas Ilmu Pendidikan Universitas Negeri Jakarta yang bekerja pada saat penyusunan skripsi. Populasi penelitian berjumlah 60 mahasiswa. Pengambilan sampel menggunakan teknik purpossive sampling. Metode penelitian yang digunakan adalah deskriptif jenis survey. Pengumpulan data dengan menggunakan kuesioner. Kuesioner yang digunakan dalam penelitian ini merupakan adaptasi alat ukur Self Regulation Questionnaire (SRQ) yang dibuat oleh Miller \& Brown, berisi 63 butir pernyataan dari tujuh indikator regulasi diri dan telah divalidasi oleh ahli. Hasil reliabilitas dengan menggunakan rumus Alpha Cronbach diperoleh hasil sebesar 0,89. Teknik analisa data yang digunakan yaitu statistik deskriptif yang dijabarkan melalui kategorisasi. Berdasarkan hasil analisa data responden secara keseluruhan, yaitu: kategori rendah terdapat 10 mahasiswa (17\%) artinya, memiliki regulasi diri rendah dalam beraktivitas termasuk bekerja dan menyusun skripsi, kategori sedang terdapat 44 mahasiswa (73\%) artinya, memiliki regulasi diri cukup dalam beraktivitas termasuk bekerja dan menyusun skripsi, dan kategori tinggi terdapat 6 mahasiswa (10\%) artinya, memiliki regulasi diri tinggi dalam beraktivitas termasuk bekerja dan menyusun skripsi. Hasil penelitian menunjukkan mahasiswa Bimbingan dan Konseling angkatan 2008-2010 memiliki regulasi diri sedang antara bekerja dan menyusun skripsi.
\end{abstract}

Kata Kunci : Regulasi diri, bekerja, skripsi, mahasiswa Bimbingan dan Konseling

\section{Pendahuluan}

Saat ini kebutuhan pendidikan menjadi sangat penting di masyarakat. Seseorang dituntut memiliki keahlian, dan kemampuan bersaing dalam menghadapi era yang penuh tantangan serta kemajuan yang

\footnotetext{
Mahasiswa Jurusan Bimbingan dan Konseling FIP UNJ,

Dosen Bimbingan dan Konseling FIP UNJ

Dosen Bimbingan dan Konseling FIP UNJ
}

sangat pesat untuk mendapatkan kehidupan yang layak. Kesempatan untuk mendapatkan pekerjaan akan lebih mudah bila mempunyai latar belakang pendidikan minimal Program Sarjana (S1). Kualitas perguruan tinggi menentukan seseorang dalam mencari pekerjaan. Seseorang yang belajar di perguruan 
tinggi disebut mahasiswa. Selama perkuliahan, banyak aktivitas yang dilakukan mahasiswa baik akademik maupun non akademik. Namun, dalam kenyataannya banyak sekali hambatan dalam kegiatan perkuliahan. Salah satu faktor yang berpengaruh bagi mahasiswa tak terkecuali yang bekerja pada saat penyusunan skripsi yaitu regulasi diri. Regulasi diri (Zimmermann, 2000) merupakan proses yang dilakukan seseorang untuk menghasilkan pikiran, perasaan, dan tindakan, merencanakan, dan mengadaptasikannya secara terus-menerus untuk mencapai tujuan-tujuan yang telah dirancang demi hasil yang positif bagi diri sendiri.

Berdasarkan studi pendahuluan, kendala yang dihadapi mahasiswa Bimbingan dan Konseling angka$\tan 2008-2010$ yang bekerja saat penyusunan skripsi, yaitu: $25 \%$ mahasiswa (5 orang) malas menyusun skripsi, 20\% mahasiswa (4 orang) bermasalah dengan dosen pembimbing, 15\% mahasiswa (3 orang) memiliki kendala topik skripsi, dan 40\% mahasiswa (8 orang) mengatur waktu bekerja dan skripsi. Pada umumnya, mereka sulit mengatur waktu bekerja dan menyusun skripsi. Fenomena mahasiswa Bimbingan dan Konseling yang bekerja dan belum lulus akan menyebabkan penumpukan mahasiswa yang masih terdaftar di kampus sehingga mengganggu proses kelulusan angkatan di atas mahasiswa yang belum lulus tersebut.

Permasalahan utama yang akan dikaji dalam penelitian ini dirumuskan dalam pertanyaan yaitu: "Bagaimana regulasi diri mahasiswa Bimbingan dan Konseling angkatan 2008-2010 yang bekerja pada saat penyusunan skripsi?"

Penelitian ini bertujuan untuk mendapatkan gambaran mengenai Regulasi Diri Mahasiswa Bimbingan dan Konseling angkatan 2008-2010 Fakultas Ilmu Pendidikan Universitas Negeri Jakarta yang bekerja pada saat penyusunan skripsi.

\section{Kajian Teori}

Regulasi diri Regulasi diri (Bandura, dalam Howard Friedman and Miriam W. Schustack, 2008) adalah proses yang dilakukan seseorang untuk mengatur pencapaian dan aksi mereka sendiri. Regulasi diri (Zimmermann, 2000) merupakan proses yang dilakukan seseorang untuk menghasilkan pikiran, perasaan, dan tindakan, merencanakan, dan meng- adaptasikannya secara terus-menerus untuk mencapai tujuan-tujuan yang telah dirancang demi hasil yang positif bagi diri sendiri. Proses regulasi diri terdiri dari tujuh tahapan (Miller \& Brown, dalam D.J. Neal, and K.B. Carey, 2005), yaitu: (1) Receiving atau menerima informasi yang relevan, yaitu langkah awal individu dalam menerima informasi dari berbagai sumber; (2) Evaluating atau mengevaluasi informasi. Menyadari seberapa besar masalah setelah mendapatkan informasi; (3) Triggering atau membuat suatu perubahan. Timbul perasaan positif atau negatif sebagai akibat dari suatu proses perbandingan hasil evaluasi sebelumnya; (4) Searching atau mencari solusi. Seseorang menyadari beberapa pertentangan antara sikap individu dalam memahami masalah dengan melakukan jenis tindakan atau aksi; (5) Formulating atau merancang suatu rencana, yaitu perencanaan aspek-aspek pokok untuk meneruskan target atau tujuan seperti waktu, aktivitas untuk pengembangan, tempat-tempat dan aspek lainnya yang mampu mendukung dengan efisien dan efektif; (6) Implementing atau menerapkan rencana, yaitu setelah semua perencanaan telah tereali-sasi, berikutnya adalah secepatnya mengarah kepada aksi-aksi atau tindakan-tindakan yang tepat mengarah ke tujuan dan memodifikasi sikap sesuai dengan yang diinginkan dalam proses; (7) Assessing atau mengukur efektivitas dari rencana yang telah dibuat. Pengukuran ini dilakukan pada tahap akhir.

Ada pun faktor-faktor yang mempengaruhi regulasi diri (Bandura, dalam Alwisol, 2011) yaitu, faktor eksternal dan faktor internal. Faktor eksternal terbagi menjadi dua cara, yaitu: (1) Standar, yaitu faktor eksternal memberi standar untuk mengevaluasi tingkah laku. Standar yang diberlakukan hasil interaksi diri sendiri dengan lingkungan sekitar; (2) Penguatan (reinforcement), faktor eksternal mempengaruhi regulasi diri dalam bentuk penguatan (reinforcement). Penguatan berupa reward atau punishment. Faktor internal terbagi menjadi tiga cara yaitu: (1) Observasi diri, adalah mengamati dan mengevaluasi keadaan diri sendiri. Observasi diri dilakukan berdasarkan faktor kualitas penampilan, orisinalitas, kuantitas penampilan, orisinalitas tingkah laku, dan kemampuan diri; (2) Proses penilaian, adalah melihat kesesuaian tingkah laku dengan standar pribadi, membandingkan tingkah laku dengan norma standar atau dengan tingkah laku orang lain, menilai 
berdasarkan pentingnya suatu aktivitas bagi dirinya, dan memberi atribusi aksi; (3) Reaksi diri, tujuan nyata yang dilakukan seseorang setelah melakukan evaluasi diri secara positif dan negatif kemudian memberikan reward atau punishment terhadap diri sendiri.

\section{Mahasiswa}

Mahasiswa(Susantoro, dalam A. Handianto, 2006) adalah seorang peserta didik berusia antara 19-28 tahun peralihan fase remaja ke dewasa awal yang sedang menempuh pendidikan di perguruan tinggi dan aktif mengikuti kegiatan di kampus meliputi kegiatan akademik dan non akademik. Seiring berjalan proses perkuliahan, mahasiswa mulai memfokuskan diri untuk skripsi sebagai jalur penyelesaian studi. Penetapan jalur penyelesaian studi dilakukan setelah mahasiswa memperoleh minimal 100 SKS dengan komposisi mata kuliah yang sesuai dengan persyaratan yang ditetapkan oleh jurusan/program studi masing-masing. Beban kredit semester untuk jalur penyelesaian studi adalah minimal 144-146 SKS.

\section{Bekerja}

Bekerja adalah sesuatu yang dilakukan oleh seseorang untuk mencari nafkah untuk diri sendiri dan keluarga. Bekerja menjadi kebutuhan pokok dalam kehidupan manusia. Bekerja menjadi penopang hidup seseorang dan keluarga sehingga tidak bergantung dan mengganggu orang lain. Seseorang bekerja terbagi menjadi 4 kategori pekerja (Syahlim \& Wibowo, 2004), yaitu: (1) pekerja tetap; (2) pekerja tidak tetap (freelance); (3) pekerja penuh (full time); dan (4) pekerja paruh waktu (part time).

\section{Mahasiswa yang bekerja}

Mahasiswa yang bekerja (Yuman, 2010) adalah seseorang yang belajar di universitas atau perguruan tinggi juga melakukan aktivitas yang memberikan penghasilan dan pengalaman di luar kampus Mahasiswa Bimbingan dan Konseling angkatan 20082010 yang bekerja pada saat penyusunan skripsi, terbagi antara lain, yaitu: (1) guru di sekolah; (2) guru bimbingan belajar atau privat; (3) freelancer; (4) wirausaha; dan bekerja di perusahaan.

\section{Metodologi Penelitian}

Penelitian ini dilakukan di Universitas Negeri Jakarta yang beralamat di Jl. Rawamangun Muka, Jakarta Timur 13220. Penelitian ini dilaksanakan Maret-April 2014.

Metode penelitian yang digunakan dalam penelitian ini adalah metode penelitian deskriptif jenis survey. Penelitian menggunakan survey bertujuan untuk mendapatkan gambaran mengenai Regulasi Diri Mahasiswa Bimbingan dan Konseling angkatan 2008-2010 Fakultas Ilmu Pendidikan Universitas Negeri Jakarta yang bekerja pada saat penyusunan skripsi.

Pengambilan sampel menggunakan teknik purpossive sampling. Sampel dan populasi dipilih sesuai dengan tujuan penelitian yaitu mencari informasi regulasi diri mahasiswa Bimbingan dan Konseling angkatan 2008-2010 yang bekerja pada saat penyusunan skripsi yang berjumlah 60 orang.

Pengumpulan data dengan menggunakan kuesioner. Kuesioner yang digunakan dalam penelitian ini merupakan adaptasi alat ukur Self Regulation Questionnaire (SRQ) yang dibuat oleh Miller $\&$ Brown, berisi 63 butir pernyataan dari tujuh indikator regulasi diri, yaitu: (1) Receiving; (2) Evaluating; (3) Triggering; (4) Searching; (5) Formulating; (6) Implementing; dan (7) Assessing.

Data penelitian mengenai regulasi diri Mahasiswa Bimbingan dan Konseling angkatan 20082010 yang bekerja pada saat penyusunan skripsi menggunakan model skala Likert yang disesuaikan dengan alat ukur Self Regulation Questionnaire (SRQ). Metode skala Likert dimulai dari skala 1 sampai skala 5 dengan keterangan yaitu Sangat Tidak Setuju (STS), Tidak Setuju (TS), Ragu-Ragu (R), Setuju (S), Sangat Setuju (SS).

Analisis uji instrumen dalam penelitian ini menggunakan pengujian validitas dan perhitungan reliabilitas instrumen. Pengujian validitas yang digunakan dalam penelitian ini menggunakan rumus Pearson product moment. Hasil r Product Moment tiap butir dibandingkan dengan tabel r Product Moment dengan ketentuan sebagai berikut: Jika rxy $>\mathrm{r}$ tabel, , maka butir dinyatakan valid, dan jika rxy $<\mathrm{r}_{\text {tabel }}$, maka butir dinyatakan tidak valid. Perhitungan reliabilitas instrumen menggunakan koefisien Alpha Cronbach. 
Gambaran penelitian regulasi diri mahasiswa Bimbingan dan Konseling angkatan 2008-2010 yang bekerja pada saat penyusunan skripsi dengan menggunakan teknik statistik deskriptif. Teknik analisa data instrumen dijabarkan melalui kategorisasi.

\section{Hasil dan Pembahasan}

Peneliti melakukan uji normalitas data dengan SPSS ver. 20 menghasilkan taraf signifikansi data $>0,05$ yaitu 0,2 . Hal ini menjadikan data berdistribusi normal.

Selanjutnya, deskripsi data secara keseluruhan dapat digambarkan sebagai berikut:

Tabel 1

Data Responden Secara Keseluruhan

\begin{tabular}{|c|c|c|l|}
\hline Kategori & F & \% & \multicolumn{1}{|c|}{ Keterangan } \\
\hline Tinggi & 6 & $10 \%$ & $\begin{array}{l}\text { Memiliki regulasi diri yang tinggi dalam } \\
\text { beraktivitas termasuk bekerja dan } \\
\text { menyusun skripsi }\end{array}$ \\
\hline Sedang & 44 & $73 \%$ & $\begin{array}{l}\text { Memiliki regulasi diri yang cukup dalam } \\
\text { beraktivitas termasuk bekerja dan } \\
\text { menyusun skripsi }\end{array}$ \\
\hline Rendah & 10 & $17 \%$ & $\begin{array}{l}\text { Memiliki regulasi diri yang rendah dalam } \\
\text { beraktivitas termasuk bekerja dan } \\
\text { menyusun skripsi }\end{array}$ \\
\hline
\end{tabular}

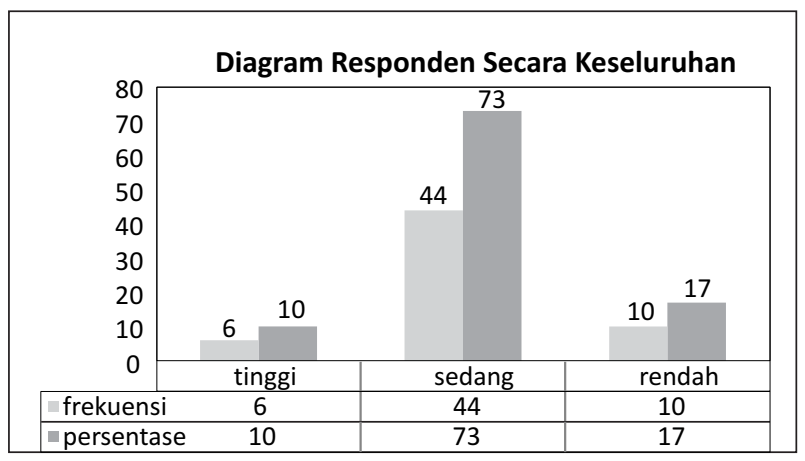

Gambar 1

Data Responden Secara Keseluruhan

Berdasarkan gambar 1, data responden secara keseluruhan menunjukkan pada kategori tinggi terdapat 6 mahasiswa (10\%) artinya, memiliki regulasi diri tinggi dalam beraktivitas, termasuk bekerja dan menyusun skripsi; kategori sedang terdapat 44 mahasiswa (73\%) artinya, memiliki regulasi diri cukup dalam beraktivitas termasuk bekerja dan menyusun skripsi; dan kategori rendah terdapat 10 mahasiswa $(17 \%)$ artinya, memiliki regulasi diri rendah dalam beraktivitas termasuk bekerja dan menyusun skripsi.

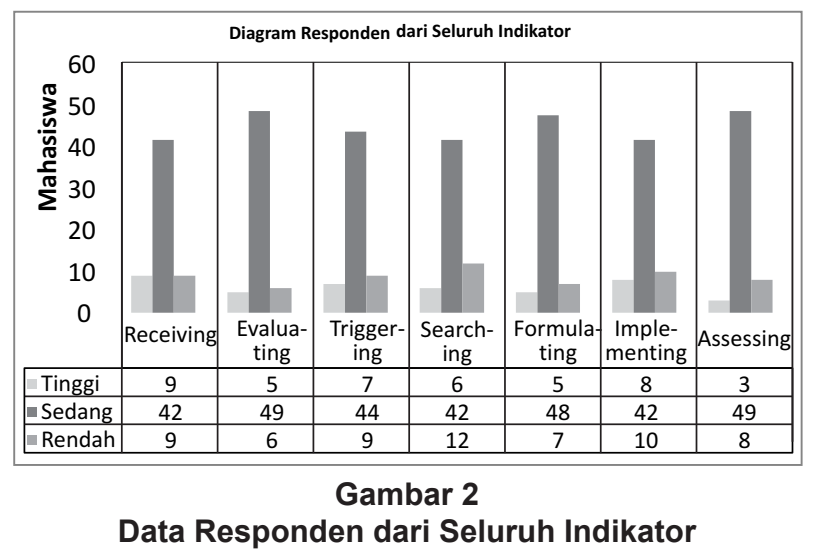

Mengenai data responden per indikator instrumen sesuai gambar 2, dapat digambarkan sebagai berikut: (1) receiving atau menerima informasi yang relevan menunjukkan 9 mahasiswa (15\%) termasuk kategori tinggi, 42 mahasiswa (70\%) termasuk kategori sedang, dan 9 mahasiswa (15\%) termasuk kategori rendah; (2) evaluating atau mengevaluasi informasi menunjukkan 5 mahasiswa (8\%) termasuk kategori tinggi, 49 mahasiswa (82\%) termasuk kategori sedang, dan 6 mahasiswa (10\%) termasuk kategori rendah; (3) triggering atau membuat suatu perubahan menunjukkan 7 (12\%) termasuk kategori tinggi, 44 mahasiswa (73\%) termasuk kategori sedang, dan 9 mahasiswa (15\%) termasuk kategori rendah; (4) searching atau mencari solusi menunjukkan 6 mahasiswa (10\%) termasuk kategori tinggi, 42 mahasiswa (70\%) termasuk kategori sedang, dan 12 mahasiswa (20\%) termasuk kategori rendah; (5) formulating atau merancang suatu rencana menunjukkan 5 mahasiswa (8\%) termasuk kategori tinggi, 48 mahasiswa $(80 \%)$ termasuk kategori sedang, dan 7 mahasiswa (12\%) termasuk kategori rendah; (6) implementing atau menerapkan rencana menunjukkan 8 mahasiswa (13\%) termasuk kategori tinggi, 42 mahasiswa (70\%) termasuk kategori sedang, dan 10 mahasiswa (17\%) termasuk kategori rendah; dan (7) assessing atau mengukur efektivitas dari rencana yang telah dibuat menunjukkan 3 mahasiswa (5\%) termasuk kategori tinggi, 49 mahasiswa (82\%) termasuk kategori sedang, dan 8 mahasiswa (13\%) termasuk kategori rendah. 
Berdasarkan pemaparan data di atas, mahasiswa Bimbingan dan Konseling memiliki persentase tertinggi pada proses Evaluating dan Assesing. Artinya, mahasiswa cukup mampu melakukan evaluasi dan mengukur efektivitas perencanaan yang telah dibuat. Mahasiswa cukup mampu memiliki strategi dan standar untuk meraih hasil yang maksimal antara bekerja dan menyusun skripsi.

Ada pun pada proses Receiving, Searching, dan Implementing, mahasiswa memiliki persentase terendah dibandingkan proses regulasi diri lainnya. Artinya, mahasiswa perlu meningkatkan kemampuan diri untuk memperoleh informasi yang lebih baik mengenai bekerja dan menyusun skripsi, percaya diri dalam melakukan perubahan dan mencari solusi saat melihat masalah atau tantangan dalam bekerja dan menyusun skripsi, dan fokus pada perencanaan, memiliki tekad yang kuat dan tidak cepat menyerah dalam bekerja dan menyusun skripsi.

Selanjutnya pada proses Triggering dan Formulating, mahasiswa memiliki persentase di atas proses Receiving, Searching, dan Implementing dan di bawah proses Evaluating dan Assesing. Artinya, mahasiswa cukup mampu mempertimbangkan cara lain untuk pengaturan diri dan siap dengan cara-cara yang ditempuh dalam bekerja dan menyusun skripsi. Mahasiswa cukup mampu merancang suatu rencana mengenai regulasi diri dalam bekerja dan menyusun skripsi.

Berdasarkan hasil analisa data responden baik secara keseluruhan maupun per indikator, menunjukkan persentase mahasiswa Bimbingan dan Konseling angkatan 2008-2010 yang bekerja di kategori sedang. Artinya, mahasiswa Bimbingan dan Konseling angkatan 2008-2010 yang bekerja memiliki regulasi diri yang cukup dalam melakukan berbagai aktivitas antara lain bekerja dan menyusun skripsi. Selaras dengan konsep regulasi diri menurut (Kanfer, Karloy, dan Zimmerman, dalam Rema Rahma Suci, 2012) adalah sebagai suatu yang memungkinkan seseorang untuk mengatur aktivitas, pikiran, dan perilaku dengan usaha yang lebih besar untuk mencapai tujuan yang diinginkannya. Hasil penelitian menjelaskan bahwa mahasiswa Bimbingan dan Konseling 2008-2010 yang bekerja memiliki informasi-informasi yang cukup mengenai bekerja dan menyusun skripsi. Mahasiswa cukup mampu meng- atur suatu rencana seperti halnya siap dengan caracara dalam menjalankan apapun, memiliki standar diri, dan mencoba untuk menjalankannya, terbiasa konsisten dalam usaha untuk mencapai tujuan, dan dapat mempertimbangkan cara lain dalam melakukan sesuatu; mencari solusi seperti halnya mampu mencapai tujuan yang telah ditetapkan, percaya diri mampu melakukan perubahan, dan mampu mencari solusi pada saat melihat masalah atau tantangan; dan melakukan perubahan seperti halnya mempunyai aturan untuk tetap konsisten dengan apapun yang terjadi, tidak cepat menyerah, dan memberi penghargaan diri terhadap pencapaian tujuan atau hasil yang maksimal dalam bekerja dan menyusun skripsi.

Selaras dengan konsep Self Regulated Learning dan Self Motivation menurut (Ormrod, 2012) dalam Human Learning yaitu seseorang yang memiliki regulasi diri yang tinggi memiliki kemampuan untuk menyelesaikan tugas-tugas; mampu disiplin dan tidak menunda-nunda tugas-tugas; mampu memiliki strategi untuk memecahkan masalah; dan mampu menetapkan reward dan punishment terhadap hasil yang telah dilakukan. Bisa dikatakan, mahasiswa Bimbingan dan Konseling angkatan 20082010 yang bekerja sudah cukup mampu memiliki kemampuan diri yang telah dijelaskan sebelumnya walaupun harus lebih menambah informasi-informasi yang penting untuk menunjang proses regulasi diri bekerja dan menyusun skripsi ke tingkat kategori tinggi.

Penjelasan lain mengenai hasil penelitian yang menunjukkan mahasiswa angkatan 2008-2010 yang bekerja berada pada kategorisasi sedang, yaitu disebabkan pula oleh jenis pekerjaan. Sebagian besar responden bekerja paruh waktu atau part time. Jadwal kerja yang tidak terlalu padat membuat responden mampu mengatur diri dalam bekerja dan menyusun skripsi walaupun intensitasnya tidak terlalu tinggi.

\section{Simpulan Dan Saran}

Data secara keseluruhan mengenai regulasi diri mahasiswa angkatan 2008-2010 yang bekerja pada saat penyusunan skripsi menunjukkan pada kategori sedang. Hal ini menunjukkan bahwa mahasiswa memiliki regulasi diri yang cukup dalam melakukan berbagai aktivitas antara lain bekerja dan menyusun 
skripsi. Mahasiswa memiliki informasi-informasi yang cukup mengenai bekerja dan menyusun skripsi. Mahasiswa cukup mampu untuk mengatur suatu rencana, mencari solusi, dan melakukan perubahan dalam bekerja dan menyusun skripsi. Selanjutnya, cara untuk meningkatkan regulasi diri ke kategori tinggi yaitu salah satunya dengan mengatur keseimbangan jadual atau agenda aktivitas bekerja dan menyusun skripsi dengan lebih baik.

Saran yang dapat disampaikan dari hasil penelitian, yaitu sebagai berikut: (1) Bagi mahasiswa, perlu memilih jenis pekerjaan yang memiliki intensitas waktu bisa seimbang dengan proses penyusunan skripsi; dan (2) Bagi jurusan Bimbingan dan Konseling, adanya usaha/program untuk percepatan penyelesaian studi antara lain adanya proses penulisan proposal skripsi yang merupakan syarat kelulusan matakuliah Pendalaman Metodologi Penelitian.

\section{Daftar Pustaka}

Alwisol. 2011. Psikologi Pendidikan Edisi Revisi. Malang: UMM Press.

Friedman, Howard and Miriam W. Schustack. 2008. Kepribadian Teori Klasik dan Riset Modern. Jakarta:
Penerbit Erlangga.

Handianto, A. 2006. Perbedaan Tingkat Stress antara Mahasiswa yang Bekerja dengan Yang Tidak Bekerja. Jakarta: Skripsi Universitas Atma Jaya.

Neal, D.J., and K.B. Carey. 2005. A Follow Up Psychometric Analysis of the Self Regulation Questionaire. Psychology Journal: Psychology of Addictive Behaviors, $19,4$.

Ormrod, Jeanne Ellis. 2012. Human Learning. USA: Person Education, Inc.

Rahma, Rema Suci, Perbedaan Self Regulation Pada Mahasiswa yang Bekerja dan Mahasiswa yang Tidak Bekerja. (http://jurnal.pdii.lipi.go.id/ admin/ jurnal/ 51083448.PDF). Diunduh tanggal 24 September 2012.

Syahlim \& Wibowo. 2004. Hubungan Antara Stress Kerja dengan Motivasi Berprestasi Pada Mahasiswa yang Bekerja Paruh Waktu. Jakarta: Skripsi Universitas Atma Jaya.

Y.R, Yuman. Fenomena Part Time Job Mahasiswa. (http:// www.senyumkita.com/kabar-senyum/fenomena-parttime-job-mahasiswa/htm). Diunduh tanggal 17 September 2012. Zimmerman, Barry J. 2000. Attaining Self-Regulation. Dalam M. Boekaerts, P. R. Pintrich \& M. Zeidner (Ed.). Handbook of Self-Regulation. San Diego: Academic Press. 